\title{
The ultrastructure of the spermatozoon of Parady- nomene tuberculata Sakai, 1963 (Crustacea, Brachyura, Dynomenidae): synapomorphies with dromiid sperm
}

\author{
B. G. M. Jamieson ${ }^{1}$, D. Guinot ${ }^{2}$ \& B. Richer de Forges ${ }^{3}$ \\ ${ }^{1}$ Zoology Department, University of Queensland; Brisbane 4072, Australia * \\ ${ }^{2}$ Laboratoire de Zoologie (Arthropodes), Muséum National d'Histoire Naturelle; \\ 61 rue Buffon, 75231 Paris Cedex 05 \\ ${ }^{3}$ ORSTOM, B. P. A5; Nouméa Cedex, Nouvelle-Calédonie
}

\begin{abstract}
The dynomenid spermatozoon, exemplified here by Paradynomene tuberculata, resembles the spermatozoa of the Dromiidae, Homolidae and lyreidine raninoids and differs markedly from those of other crabs (the heterotreme, thoracotremes, raninines and raninoidines) in the depressed, discoidal form of the acrosome and the capitate form of the perforatorium. Four or five apparent dynomenid - dromiid sperm synapomorphies are recognizable. (1) Dynomenids ( $P$. tuberculata) and dromiids differ from homolids and lyreidines in the greater depression of the acrosome (ratio of length to width $=0.3$ ); (2) the capitate head of the perforatorium is bilaterally prolonged in $P$. tuberculata as in dromiids though symmetrical in homolids; (3) dynomenid and dromiid sperm lack the - albeit variably developed - posterior median process of the nucleus seen in homolids, anomurans, raninoids and lower heterotremes; (4) $P$. tuberculata, like dromiids and less distinctly homolids, has an apical protuberance of subopercular material through the opercular perforation, unknown in other crabs, being distinct from the apical button of thoracotreme sperm; (5) a less certain synapomorphy is the anterolateral electron-pale peripheral zone of the acrosome. These synapomorphies endorse a sister-group relationship of dynomenids and dromiids, $P$. tuberculata sperm differs notably from the sperm of dromiids in the more complex zonation of the acrosome. The perforatorium lacks the radial rays ("spiked wheel") of homolid sperm and does not show the "amoeboid" form seen in lyreidines. Absence of internal corrugations of the perforatorial chamber is a major difference from all examined raninids. Centrioles are only very tentatively identifiable. Nuclear arms are absent in glutaraldehyde fixed spermatozoa of $P$. tuberculata and have not been observed in the dromiid Petalomera lateralis but are present as three small radial vertices in the dromiid Dromidiopsis edwardsi and in homolids. P. tuberculata resembles Petalomera lateralis in the large size of the sperm nucleus relative to the acrosome compared with $D$. edwardsi and homolids.
\end{abstract}

\section{INTRODUCTION}

The "Dynomènes" were placed by $\mathrm{H}$. Milne Edwards (1837) near the Dromiidae within the Anomura, and contained, at that time, the single genus Dynomene Latreille with one species Dynomene hispida Desmarest, 1825. At present the family

- Address correspondence to Professor B. G. M. Jamieson. 
Dynomenidae Ortmann, 1892, contains three genera (Dynomene Latreille, Acanthodromida A. Milne Edwards, and Paradynomene Sakai, 1963). The Dynomenidae, to which numerous fossils have been attributed, are amongst the most ancient crabs known (Jurassic). They precede the Dromiidae (cf. Glaessner, 1969). Despite its age, the family is very poorly known. Traditionally, the Dynomenidae have been placed alongside the Dromiidae within the Dromiacea; alternatively, they have been given subfamilial rank, as the Dynomeninae, within the Dromiidae (for instance by Bouvier, 1940). Wright \& Collins (1972), placed the genus Acanthodromia and its fossil relatives in a separate family Prosopidae von Meyer and subfamily Pithonotinae Glaessner while preserving Dynomene and related fossils (Paradynomene was ignored) in the Dynomenidae.

Guinot (1978) ranked dynomenids as a family in the superfamily Dromioidea, placed with the Homolodromioidea in a subsection Dromiacea, within the section Podotremata. The Podotremata also contain the doubtfully monophyletic subsection Archaeobrachyura, consisting of the Homoloidea, Raninoidea and Cyclodorippoidea (= Tymoloidea). Monophyly of the Podotremata has been questioned (Jamieson, 1990, 1991) as they are defined by two symplesiomorphies, coxal location of the male and female pores. In contrast, brachyurans of the Heterotremata and Thoracotremata are synapomorphic in the sternal location of the female pores and development of the spermatheca as a diverticulum of the oviduct. The Thoracotremata are further apomorphic in the completely sternal location of the male pores - an advance on the coxo-sternal location seen in some heterotremes.

The Dynomenidae are associate with the Dromiidae, in addition to their fundamental podotreme characters (female and male orifices coxal; presence of spermathecae; and external fertilization), by numerous traits such as the disposition of the antennules and antennae, the presence of vestigial uropods, and the similar endophragmal thoracic system. Separation into two distinct families, Dromiidae and Dynomenidae, is justified by a large number of incontestable differences (Guinot, 1979, 1993a) which need not be detailed here but which include complete modification of the coxa of P5 as a penis. Despite the more brachyuran facies of some species, several features of the Dynomenidae appear to be plesiomorphic and to accord with the earlier appearance of dynomenids relative to dromiids. Unlike the dromiids, carriage of camouflage on P5 is unknown. The extremity of each P5 of these forms a very small pincer (Acanthodromia, Dynomene spp.) or the dactyl is greatly reduced (Dynomene spp., Paradynomene) (A. Milne Edwards \& Bouvier, 1902; Guinot, 1993a).

Ontogenetic observations on dynomenids are very rare and fragmentary. Only Rice (1981) has described a prezoea, obtained from an embryo attached to a female of Acanthodromia erinacea A. Milne Edwards, and he concludes that "If these zoeae of Acanthodromia are typical of the Dynomenidae then this family, like the Dromiidae, has larval characters which are clearly Anomuran". This observation accords with association of the Dromiidae with paguroid hermit crabs on the basis of 18S rRNA sequences by Spears et al. (1992). Nevertheless, this putative relationship requires further investigation.

The genus Paradynomene Sakai is monotypic for Paradynomene tuberculata Sakai, 1963 (formerly known only from two localities in Japan), which is here recorded from New Caledonia at greater depths. The carapace is subquadrilateral, the dorsal surface areolate, its border armed with teeth, the entire body strongly ornamented (including the 
branchiostegite), the anterior ventral region inclined perpendicularly relative to the dorsal surface and forming with the merus of maxilliped 3 a triangular area below which the internal surface of the chelipeds is applied, the anterior border of the buccal frame notched by two orifices, maxillipeds 3 operculiform (except the two large latero-external orifices), and disposed on two planes (the exposed merus which is ornamented, the ischium depressed, smooth and setiferous, as is the exopodite against which the fingers of the pincer are opposed ${ }_{i}$ P5 with the ischio-basis fused to the merus and with a minute, rudimentary dactylus). This copatation of the entire anteroventral surface of maxillipeds 3 with the chelipeds constitutes a unique case in the Dynomenidae and denotes an advanced level of evolution of Paradynomene within the group (Guinot, 1993a).

Studies of spermatozoal ultrastructure have revealed a distinctive sperm type for each of the families Dromiidae (Brown, 1966; Jamieson, 1990, 1991; Jamieson et al., 1993) and Homolidae (Guinot et al., 1993). Homolids differ in the "spiked wheel" form of the head of the perforatorium, contrasting with the smooth outline and bilateral symmetry of that of dromiids. Dromiid and homolid sperm nevertheless share notable features, the depressed form of the acrosome and the capitate form of the perforatorium. These two characters have recently (Jamieson, Guinot \& Richer de Forges, in preparation) been demonstrated also in the ranininoid Lyreidus brevifrons, and possibly constitute dromiidhomolid-raninid synapomorphies supportive of recognition by Guinot (1978) of the Archaeobrachyura.

In the present study we investigate sperm ultrastructure in a species of the Dynomenidae, Paradynomene tuberculata for its interest per se and with the aim of testing the monophyly of the Dromioidea sensu Guinot (1978), consisting of the Dromiidae and Dynomenidae.

\section{MATERIALS AND METHODS}

Specimens of Paradynomene tuberculata were collected by B. Richer de Forges during the SMIB 8 Cruise on the R.V. "Alis" 26 January-3 February 1993, at station DW $183,330-367$ metres depth, $23^{\circ} 18.27^{\prime} \mathrm{S}$. $168^{\circ} \mathrm{O} 4.95^{\prime} \mathrm{E}$, on the top of a seamount. Portions of the testes and male ducts were fixed in $3 \%$ glutaraldehyde in $0.1 \mathrm{M}$ sodium phosphate buffer ( $\mathrm{pH} 7.2$ ), with $3 \%$ sucrose, at $4^{\circ} \mathrm{C}$ for $2 \mathrm{~h}$ and despatched in the fixative to Brisbane for further processing. On receipt in Brisbane they were washed in buffer; post-fixed for $80 \mathrm{~min}$ in similarly buffered $1 \%$ Osmium tetroxide; washed in three $15 \mathrm{~min}$ changes of buffer; dehydrated through an ethanol series; and infiltrated and embedded in Spurr's epoxy resin. Sections were cut with diamond knives, on an LKB 2128 UM IV microtome. Thin sections, $50-80 \mathrm{~nm}$ thick, were collected on carbon stabilized colloidin-coated 200 mesh copper grids, stained for $30 \mathrm{sec}$ in Reynolds' lead citrate, rinsed in distilled water, stained for $1 \mathrm{~min}$ in $6 \%$ aqueous uranyl acetate, rinsed in distilled water, stained for a further $30 \mathrm{sec}$ in lead citrate, before final rinsing. Electron micrographs were taken on an Hitachi 300 electron microscope at $75 \mathrm{kV}$ and a JEOL 100 at $60 \mathrm{kV}$. For light microscope observations, small portions of glutaraldehyde-fixed testes were squashed under a coverslip on a microscope slide to release spermatozoa and these were photographed under Nomarski contrast with an Olympus BH2 microscope. 


\section{RESULTS}

\section{General}

The male ducts of Paradynomene tuberculata contain numerous closely adpressed sub-spheroidal, thin-walled spermatophores, each containing many spermatozoa. Spermatozoa are illustrated semidiagrammatically in Figure 1, in light microscope micrographs in Figures 2A, B, and in transmission electron micrographs in Figures 2C, $D_{i}$ $3 \mathrm{~A}-\mathrm{E}$. Spermatozoa are $5.0-5.3 \mu \mathrm{m}$ wide (mean of $4=5.5 \mu \mathrm{m}$ ), and $3.5-4.7 \mu \mathrm{m}$ in anteroposterior thickness (mean of $5=4.2 \mu \mathrm{m}$ ). Almost the entire width of a large anterior portion of the spermatozoon (Fig. 1) consists of the anteroposteriorly depressed acrosome. The acrosome is covered, with the exception of its anterior, opercular pole, by a thin layer of nuclear material and has approximately the form of a concavo-convex thick disc, convexity anterior, with a central, opercular protrusion. The nucleus is electron-pale but is laced with innumerable slender, dense chromatin fibres. A thin layer of vestigial cytoplasm is present between the posterior face of the acrosome and the nucleus. The cytoplasm shows occasional short extensions into the nucleus.

The longitudinal axis of the Paradynomene acrosome is occupied by a capitate perforatorium with a short, wide stalk. The expansion is wider in one radius than in that at right angles (Figs $2 \mathrm{C}, \mathrm{D}$ ). There is no division of the head into radial rays.

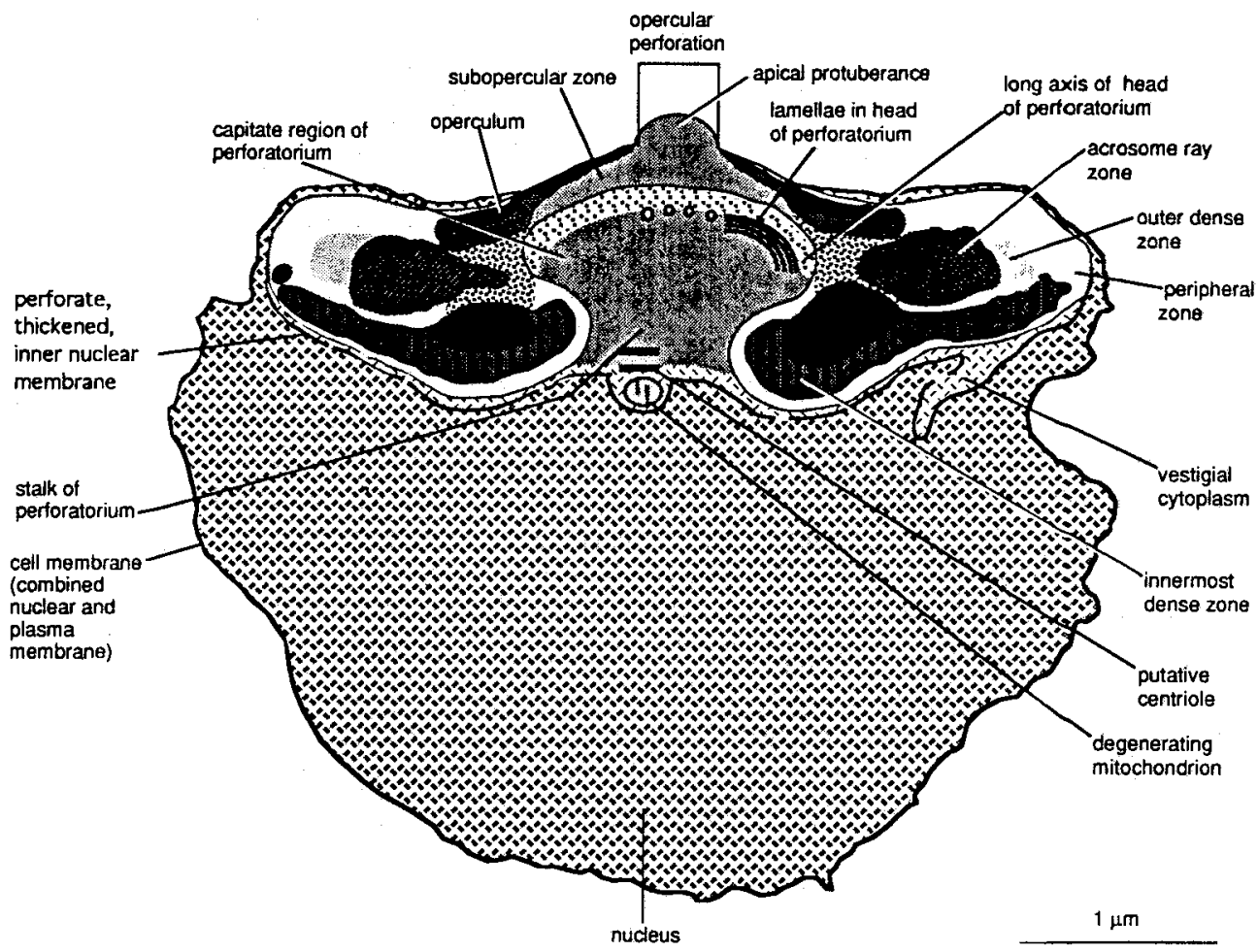

Fig. 1. Paradynomene tuberculata. Semidiagrammatic vertical longitudinal section of the spermatozoon traced from a transmission electron micrograph 
A low dome-shaped or low conical, dense layer, with a narrow apical interruption, covers the anterior limit of the perforatorium and extends laterally over much of the anterior aspect of the acrosome vesicle; this layer is identifiable with the operculum of the sperm of anomurans, dromiids, homolids, raninids and higher crabs. It is covered by the general acrosome membrane and the plasma membrane of the sperm cell.

Nuclear arms are absent as determined by transmission electron micrographs of transversely sectioned spermatozoon and by light microscopy of glutaraldehyde fixed sperm.

\section{Acrosome}

The acrosome is a thick disc (Figs 1, 2C, D, 3A). The anterior surface of the acrosome is gently domed over the operculum, which occupies more than half of its total width, but the region of the acrosome vesicle surrounding the operculum forms a wide torus (Figs $2 \mathrm{C}, \mathrm{D}, 3 \mathrm{~A})$. The width of the acrosome vesicle, in sagittal longitudinal section, is $3.3-5 \mu \mathrm{m}$ (mean of $7=4.3 \mu \mathrm{m}$ ); its antero-posterior thickness is $1.3-1.8 \mu \mathrm{m}$ (mean of $7=1.5 \mu \mathrm{m}$ ); ratio length: width $=0.34$ (mean of 7 ). The vesicle is bounded by a unit acrosomal membrane around its entire periphery, including the lining of the perforatorial chamber (Figs $2 \mathrm{C}, \mathrm{D}, 3 \mathrm{~A}$ ). A separate layer identified as the "capsule" in many brachyuran sperm is not apparent.

The contents of the acrosome vesicle, peripheral to the axial perforatorium (described below), show a zonation (Figs 1, 2C, D, 3A) which is more conspicuously horizontal than concentric. Six zones or regions are discernible in the acrosome contents, with their own peculiar features. These include: (1) The operculum, which is 1.9-3.1 $\mu \mathrm{m}$ wide (mean of $7=2.4 \mu \mathrm{m}$ ), and appears in vertical section as a dome-shaped or low conical moderately electron-dense plate, the anterior layer of which forms a very thin strongly electron-dense zone with bead-like swelling at irregular intervals thickening at its outer rim. The operculum is interrupted, centrally, by a hiatus; (2) moderately dense material protrudes from below the operculum through the perforation as an apically rounded cone. The layer of which the protuberance is an extension is here termed the subopercular zone, though homology with a zone of the same name in other brachyurans is uncertain (Jamieson et al, 1993). The subopercular zone directly overlies the capitate expansion of the perforatorium. The four remaining zones of the acrosome vesicle include: (3) the innermost zone, surrounding the stalk of the perforatorium. This occupies approximately the posterior half of the acrosome, extending from the periphery of the stalk of the perforatorium, from which it is separated by a narrow pale layer bounded centrally by the membrane which encloses the stalk, to the posterolateral wall of the acrosome. Its anteroposterior extent is greatest near the perforatorium and it decreases more peripherally to a platelike form for more than half of its transverse extent. Its outer edge in longitudinal section of the sperm is often accompanied by small detached portions of the same composition. In cross-section these are seen to represent irregularities of the edge of this zone. Throughout the entire extent of this zone, a posterior layer, including the whole of the lateral plate and the thickened central portion, shows wide cross striations. The striated region cups a rounded homogeneous zone, which is continuous with it and is not here separately named. Anterior to the innermost zone lies (4) a zone, the contents of which have the appearance of parallel dense lines separated by pale lines (tubules?), giving in longitudinal sagittal section a tortuous honey-comb-like or 

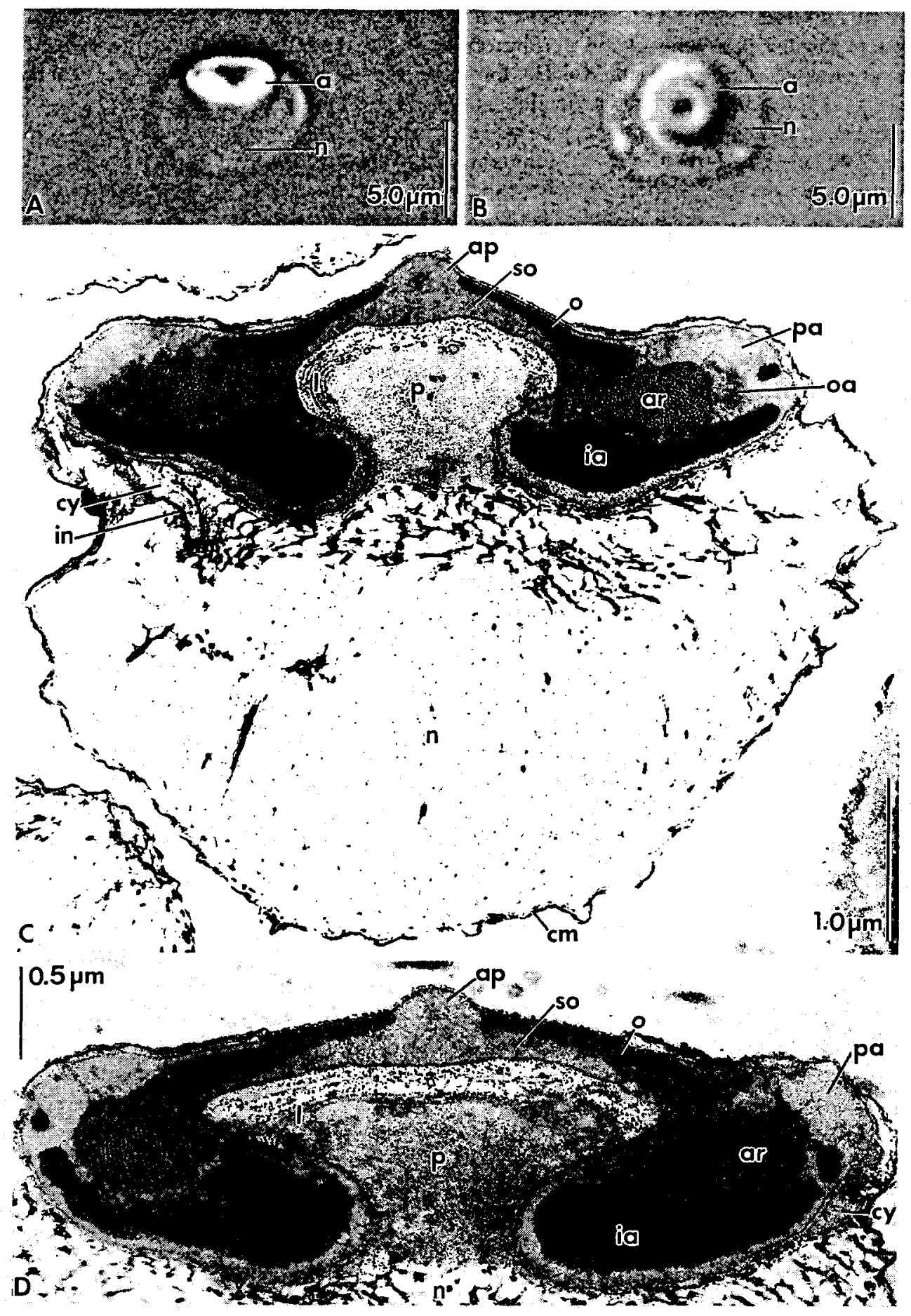
finger-print-like appearance (Figs 2C, D, 3A, D), which appears to be identifiable with the acrosome ray zone of other brachyuran sperm; (5) a small indistinct dense region immediately lateral to the acrosome ray zone may represent an outer acrosome zone. This is not seen in some sagittal longitudinal sections (e.g. Fig. 2B), indicating that it may be intermittent in extent or possibly that it is not constantly present; (6) an electron-pale zone, the peripheral zone, fills the anterolateral region of the acrosome.

The centre of the acrosome vesicle is penetrated by a stout vertical column of dense material which widens apically so as to attain the form of a closed mushroom in sagittal section (Figs 1A, B, 3A, E), consistent with its possessing a capitate structure, the whole being the putative perforatorium. Its stalk is circular in cross-section. It has not been possible to obtain transverse sections of the head, but it appears from longitudinal sagittal sections that it is longer in one diameter than in that at right-angles. The long axis of the head measures $2.3-2.7 \mu \mathrm{m}$ (mean of $2=2.5 \mu \mathrm{m}$ ), while the shorter axis is $1.1-2.0 \mu \mathrm{m}$ (mean of $7=1.5 \mu \mathrm{m}$ ). A thick anteriormost layer of the perforatorial head is filled with dense granules. In places these show a tendency to form layers, resembling rough endoplasmic reticulum (Figs 2C, D, 3A, B, E).

\section{Nucleus}

The nucleus (Figs 1A, 2C) forms approximately two thirds of the length of the spermatozoon, being at least twice as long in anterior posterior extent as the acrosome which surmounts it. The acrosome is thinly invested by nuclear material up to the level of the base of the operculum. The nuclear contents consist of a pale matrix containing a reticulum of fine putative DNA fibrils (Figs 2C, D, 3A, C). The nuclear material is in direct contact with the cell membrane and a discrete nuclear membrane is not visible. However, the cell membrane surrounding the nucleus is not a simple unit membrane, and in places is seen to consist of two apposed membranes, presumably the nuclear envelope and the plasma membrane. A dense but interrupted inner nuclear membrane separates the nucleus from the cytoplasm. The plasma membrane continues apically over the surface of the acrosome to which it is closely adherent, without the intervention of cytoplasm (Figs 2C, D, 3A). No nuclear processes or arms are observable.

\section{Centrioles}

Faint structures which may be degenerating centrioles have been seen at the posterior limit of the perforatorial chamber in Paradynomene but their nature can only be regarded as uncertain (Fig. 3B).

Fig. 2. Paradynomene tuberculata. A, B. Light micrographs of two spermatozoa. A: A slightly oblique, anterolateral view. B: An anterior view. C, D: Transmission electron micrographs of vertical longitudinal sections of the spermatozoon; through $C$, the lesser, and $D$, the greater width of the capitate perforatorium. Abbreviations (Figs 2 and 3): a - acrosome; ap - apical protuberance; ar acrosome ray zone; c - putative centriole; ca - capsule; $\mathrm{cm}$ - cell membrane; cy - cytoplasm; $\mathrm{dm}$ degenerating mitochondrion; ia - inner acrosome zone; in - inner nuclear membrane; 1 - lamellae; $\mathrm{n}$-nucleus; o-operculum; oa-outer acrosome zone; $\mathrm{p}$-perforatorium; pa-peripheral acrosome zone; so - subopercular zone 


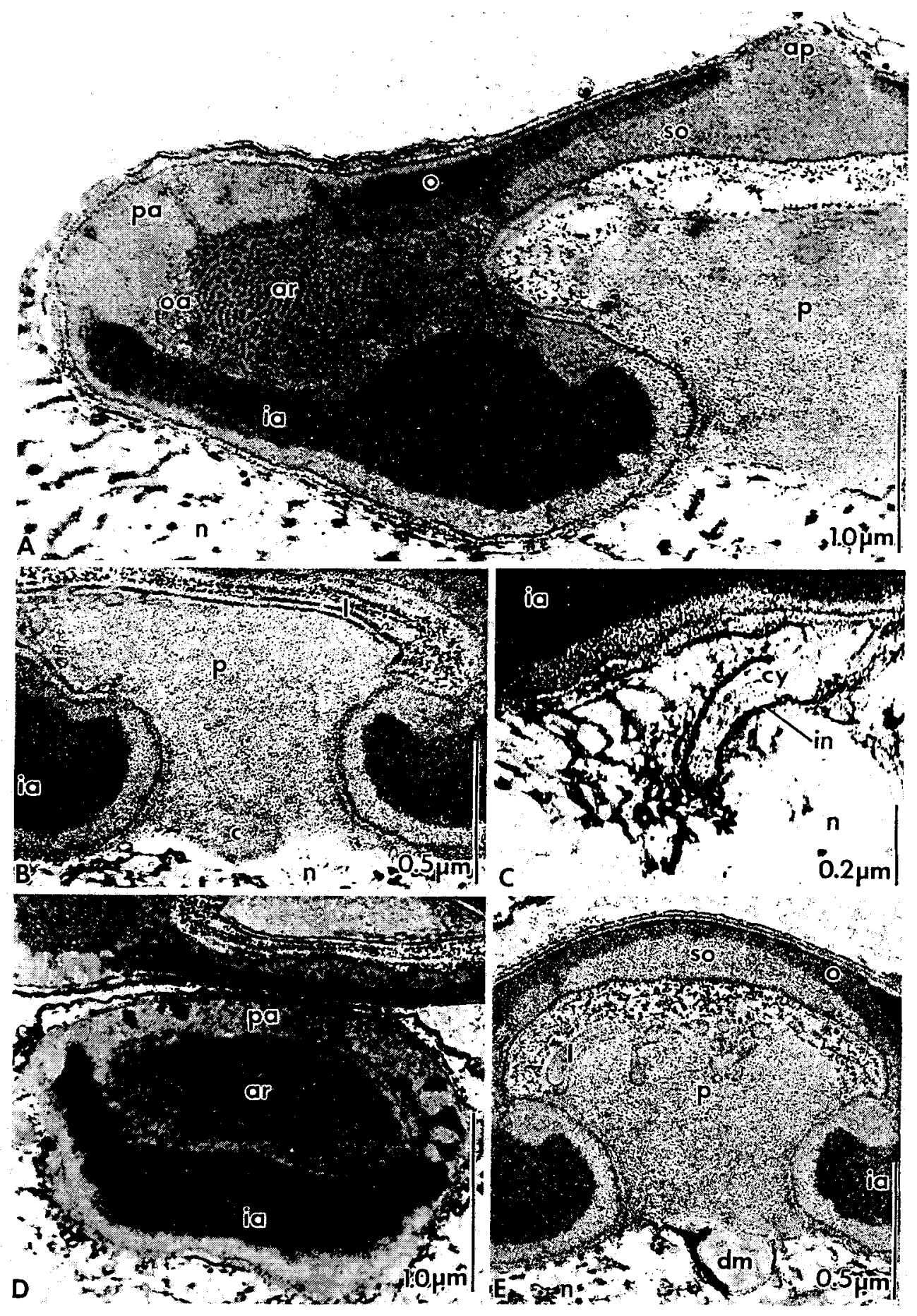




\section{DISCUSSION}

Some comparison between the sperm of dynomenids, dromiids (Jamieson, 1990), homolids (Guinot et al., 1993) and lyreidine raninids is made in Table 1. Lyreidines are included in the comparison, because of features which their sperm share with dynomenids, which are not seen in the investigated sperm of the Ranininae (Jamieson, 1989) and Raninoidinae (Jamieson, Guinot \& Richer de Forges, in preparation). In the present work, Lyreidinae connotes, among others, the genus Lyreidus de Haan, 1841 (sensu lato, including Lysirude Goeke, 1986); by Raninoidinae Lörenthey and Berlen, 1929, we intend the genus Raninoides H. Milne Edwards and some other related genera; the subfamily Ranininae de Haan is therefore reduced to the single genus Ranina Lamarck, 1801 (Guinot, 1993b).

Dynomenid spermatozoa, exemplified here by Paradynomene tuberculata, resemble the spermatozoa of the Dromiidae and Homolidae (Guinot et al., 1993) and lyreidine

Table 1. Comparison of the spermatozoa of Dynomenidae, Dromiidae, Homolidae and lyreidine raninoids

\begin{tabular}{|c|c|c|c|c|}
\hline Character & $\begin{array}{l}\text { Dynomenidae } \\
\text { (P.tuberculata) }\end{array}$ & $\begin{array}{l}\text { Dromiidae } \\
\text { (4 species) }\end{array}$ & $\begin{array}{l}\text { Homolidae } \\
\text { (7 species) }\end{array}$ & $\begin{array}{c}\text { Lyreidinae } \\
\text { (L. brevifrons) }\end{array}$ \\
\hline $\begin{array}{l}\text { Acrosome } \\
\text { depressed }\end{array}$ & strongly & strongly & moderately & moderately \\
\hline Perforatorium & capitate & capitate & capitate & capitate \\
\hline $\begin{array}{l}\text { Symmetry } \\
\text { of perforatorium }\end{array}$ & bilateral & bilateral & radial & 'amoeboid' \\
\hline $\begin{array}{l}\text { Head with radial } \\
\text { rays }\end{array}$ & absent & absent & present & 'amoeboid' \\
\hline $\begin{array}{l}\text { Posterior median } \\
\text { process }\end{array}$ & absent & absent & present & present \\
\hline Nuclear arms & absent & $\begin{array}{l}3 \text { vertices or } \\
\text { (as in } \\
\text { Petalomera) } \\
\text { absent? }\end{array}$ & 3 vertices & 3 vertices \\
\hline Nuclear arms & - & $\begin{array}{l}\text { if present, lack } \\
\text { microtubules }\end{array}$ & $\begin{array}{l}\text { lack } \\
\text { microtubules }\end{array}$ & $\begin{array}{l}\text { lack } \\
\text { microtubules }\end{array}$ \\
\hline Operculum & $\begin{array}{l}\text { with dense } \\
\text { outer layer }\end{array}$ & $\begin{array}{l}\text { with dense } \\
\text { outer layer }\end{array}$ & $\begin{array}{l}\text { with dense } \\
\text { outer layer }\end{array}$ & $\begin{array}{l}\text { uniformly } \\
\text { dense }\end{array}$ \\
\hline Operculum & perforate & perforate & perforate & perforate \\
\hline Acrosome ray zone & present & present & absent & absent \\
\hline $\begin{array}{l}\text { Peripheral } \\
\text { acrosome zone }\end{array}$ & present & present & absent & $\begin{array}{l}\text { present, differs } \\
\text { from dromioids }\end{array}$ \\
\hline
\end{tabular}

Fig. 3. Paradynomene tuberculata. A: Vertical longitudinal section (LS) through the acrosome. B: LS through the perforatorium and the putative centriole. C: LS of the spermatozoon, showing the vestigial cytoplasm, the incomplete inner nuclear membrane and the fine putative DNA fibrils. D; LS of the acrosome, showing transversely striated pattern of the inner acrosome zone. E: LS spermato. zoon, showing lamellae and dense granules in the head of the perforatorium 
raninoids and differ markedly from those of other crabs (the heterotreme-thoracotreme assemblage [see Jamieson, 1991], and the Ranininae and raninoidinae) in the discoidal form of the acrosome and the capitate form of the perforatorium. The dynomenid and dromiid sperm differ from those of homolids and lyreidines in the greater depression of the acrosome (ratio of length to width $=0.3$, against $0.4-0.7$ in homolids and 0.5 in Lyreidus) and the form of the head of the perforatorium which lacks the radial rays ("spiked wheel") of homolid sperm (Guinot et al., 1993) or the "amoeboid" form of Lyreidus sperm (Jamieson, Guinot \& Richer de Forges, in prep.). Bilateral symmetry of the head of the perforatorium, seen in Paradynomene, also occurs in dromiid sperm, being more pronounced in that of Dromidiopsis and about equally developed in Petalomera. Its symmetry is not described for Dromidia antillensis by Brown (1966). The tendency of dense granules in the perforatorial head to form layers, resembling rough endoplasmic reticulum, is reminiscent of the condition in Dromidiopsis.

Absence of internal corrugations of the perforatorial chamber is a major difference of Paradynomene from the Raninoidea. A separate layer identified as the "capsule" in many brachyuran sperm, including Petalomera lateralis", and tentatively recognized, though only basally, in Dromidiopsis is not apparent.

The occasional short extensions of the cytoplasm into the nucleus in Paradynomene are probably identifiable with those termed extensions of the capsule in Petalomera. A few degenerating mitochondria observed in the cytoplasm of Paradynomene sperm are also seen in Dromidiopsis and in homolids (though more conspicuous). Mitochondria are unknown in Petalomera sperm. Centrioles are only very tentatively identifiable in paradynomenid sperm and have not been seen in dromiid (Petalomera and Dromidiopsis) sperm, but are present in those of homolids.

In Paradynomene, as in Petalomera lateralis, the bulk of the spermatozoon is occupied by the nucleus, whereas in Dromidiopsis the nucleus comprises only about one third of the length of the spermatozoon. This feature has questionable phylogenetic significance. Nuclear arms are absent in glutaraldehyde fixed spermatozoa of Paradynomene tuberculata, and have not been observed in Petalomera lateralis, but are present as three small radial vertices in the dromiid Dromidiopsis edwardsi and in homolids, and three stubby arms are reported for Dromidia antillensis by Brown (1966). Three arms are also seen in Lyreidus. Paradynomenid and dromiid sperm lack the - albeit variably developed - posterior median process of the nucleus seen in homolids, anomurans and lower heterotremes. The acrosome is covered by a thin extension of the nucleus in Paradynomene tuberculata and in D. edwardsi, whereas in Petalomera lateralis it is wholly superficial on the nucleus. Paradynomene tuberculata resembles Petalomera lateralis in the large size of the sperm nucleus relative to the acrosome compared with $D$. edwardsi and homolids. $P$. tuberculata, like dromiids, has an apical protuberance of subopercular material through the opercular perforation. This is probably homologous with a less distinct protrusion of subopercular material through the perforation which occurs in homolid sperm (Guinot et al., 1993). It is unknown in other crabs, being distinct from the apical button of thoracotreme sperm. Homology with the subopercular zone of other brachyurans is uncertain (Jamieson et al., 1993). Apical perforation of the operculum occurs also in dromiids and homolids and also in raninoids, cyclodorippoids and

- Now Stimdromia lateralis (Gray, 1831) 
lower (e.g. majid) heterotremes (Jamieson, 1991; Jamieson, Guinot \& Richer de Forges, in prep.).

The contents of the acrosome vesicle, peripheral to the axial perforatorium (described below), show a zonation more closely resembling that in the acrosome of Petalomera than that of Dromidiopsis, in that the zones are more conspicuously horizontal than concentric. Nevertheless, as in Dromidiopsis, six zones or regions are discernible in the acrosome contents. The homology of some of these regions, particularly the outer dense zone and the acrosome ray zone, in Paradynomene with their counterparts in dromiids is not unequivocal. However, homology of the operculum, subopercular zone, and peripheral zone may confidently be accepted. The inner dense zone in Paradynomene appears homologous with the large lower zone in Petalomera but possibly with only part of the inner zone of Dromidiopsis. The inner or proximal electron-dense layer in $D$. antillensis is supposedly composed of material very similar to that of the true acrosomal ray zone of the sperm of heterotremes, astacids, and some hermit crabs (Brown, 1966; Jamieson, 1990; Tudge, 1992). That the small indistinct dense region immediately lateral to the acrosome ray zone in Paradynomene is homologous with the well-developed outer acrosome zone seen in Dromidiopsis is particularly uncertain, and it is questionable that it merits recognition of a distinct zone. The electron-pale peripheral zone which fills the anterolateral region of the acrosome in Paradynomene is less developed in Petalomera but is more extensive in Dromidiopsis, owing to failure of the inner acrosome zone to extend far laterally.

Despite some questions with regard to homology of zones in the acrosome vesicle, the similarity of the sperm of $P$. tuberculata to those of dromiids, particularly that of Petalomera is striking and is unequalled by those of any other brachyurans. After the dromiids, the next most similar spermatozoa are those of the Homolidae. A sister-group relationship of dynomenids and dromiids is spermatologically endorsed. Although $P$. tuberculata sperm differs from the sperm of dromiids in the more complex zonation of the acrosome, spermatological differences from dromiids are slight, compared with classical morphological differences which separate Paradynomene, and therefore dynomenids, from their sister-group, the Dromiidae.

Acknowledgements. We are grateful to $\mathrm{C}$. Tudge for processing glutaraldehyde-preserved dynomenid material received from B. R. F., and for his careful reading of the manuscript. L. Daddow and $\mathrm{D}$. Scheltinga are thanked for excellent technical assistance. This work was made possible by Australian Research Council funding.

\section{LITERATURE CITED}

Bouvier, E.-L., 1940. Décapodes marcheurs. - Faune Fr. 37, 404.

Brown, G. G., 1966. Ultrastructural studies of crustacean spermatozoa and fertilization. Ph. D. Thesis, Univ. of Miami, 239 pp.

Glaessner, M, F., 1969. Decapoda. In: Treatise on invertebrate paleontology. Part R: Arthropoda 4, Vol. 2. Ed. by R. C. Moore. Univ. of Kansas Press, Boulder, Colorado, 399-533; 626-628.

Guinot, D., 1978. Principes d'un classification évolutive des Crustacés Décapodes Brachyoures. Bull. biol. Fr. Belg. 112, 211-292.

Guinot, D., 1979. Données nouvelles sur la morphologie, la phylogenèse et la taxonomie des Crustacés Décapodes Brachyoures. - Mém. Mus. nat. Hist. nat., Paris (A: Zool.) 112, 1-354.

Guinot, D., Jamieson, B. G. M. \& Richer de Forges, B., 1993. Relationship of Homolidae and 
Dromiidae: evidence from spermatozoal ultrastructure (Crustacea, Decapoda). - Acta Zool. 74 (in press).

Guinot, D., 1993a. Données nouvelles sur les crabes primitifs (Crustacea Decapoda Brachyura Podotremata). - C.r. Acad. Sci. Paris (Sér. 3), 316; (in press).

Guinot, D., 1993b. Données nouvells sur les Raninoidea de Haan, 1841 (Crustacea Decapoda Brachyura Podotremata). - C. r. Acad. Sci. Paris (Sér. 3), 316 (in press).

Jamieson, B. G. M., 1989. Ultrastructural comparison of the spermatozoa of Ranina ranina (Oxystomata) and of other crabs exemplified by Portunus pelagicus (Brachygnatha) (Crustacea, Brachyura). - Zoomorphology 109, 103-111.

Jamieson, B. G. M., 1990. The ultrastructure of the spermatozoa of Petalomera lateralis (Gray) (Crustacea, Brachyura, Dromiacea) and its phylogenetic significance. - Invertebr. Reprod. Dev. $17,39-45$.

Jamieson, B. G. M., 1991. Ultrastructure and phylogeny of crustacean spermatozoa. - Mem. Qld. Mus. 31, 109-142.

Jamieson, B. G. M., Tudge, C. C. \& Scheltinga, D. M., 1993. The ultrastructure of the spermatozoon of Dromidiopsis edwardsi Rathbun, 1919 (Crustacea, Brachyura, Dromiidae): confirmation of a dromiid sperm type. - Aust. J. Zool. 41 (in press).

Milne Edwards, $H$., 1837. Histoire naturelle des Crustacés comprenant l'anatomie, la physiologie et la classification de ces animaux. Librairie Encyclopédique de Roret, Paris, 2, 1-532.

Milne Edwards, A. \& Bouvier, E.-L., 1902. Reports on the results of dredging, under the supervision of Alexander Aggasiz, in the Gulf of Mexico (1877-78), in the Caribbean Sea (1878-79), and along the Atlantic Coast of the United States (1880), by the U.S. Coast Survey Steamer "Blake". XXXIX. Les Dromiacés et Oxystomes. - Mem. Mus. comp. Zool. Harv. 27 (1), 1-127.

Rice, A. L., 1981. The zoea of Acanthodromia erinacea A. Milne Edwards; the first description of a dynomenid larva (Decapoda, Dromioidea). - J. crust. Biol. 1, 174-176.

Sakai, T., 1963. Notes from the carcinological fauna of Japan (1). - Res. Crust. Tokyo 1, 12-17.

Spears, T., Abele, L. G. \& Kim, W., 1992. The monophyly of brachyuran crabs: a phylogenetic study based on 185 rRNA. - Syst. Biol. 41, 446-461.

Tudge, C. C., 1992. Comparative ultrastructure of hermit crab spermatozoa (Decapoda: Anomura: Paguroidea). - J. crust. Biol. 12, 397-409.

Wright, C. W. \& Collins, J. S. H., 1972. British cretaceous crabs. Paleontographical Soc., London, $114 \mathrm{pp}$. 